\title{
Investigation of quality characteristics and alcohol content in commercial Korean fermented sources
}

\author{
Na-Young Gil, So-Young Kim, Hye-Sun Choi, Shin-Young Park, Jae-Hyun Kim* \\ Fermented Food Science Division, Department of Agrofood Resources, National Institute of Agricultural Science, \\ RDA, Wanju 55365, Korea
}

\section{시판 장류의 알코올 함유량 및 품질특성 조사}

\author{
길나영 · 김소영 · 최혜선 · 박신영 · 김재현* \\ 농촌진흥청 국립농업과학원 발효식품과
}

\begin{abstract}
The purpose of this study was to investigate alcohol content of commercial Korean fermented sources and to analyze the quality parameters such as titratable acidity, $\mathrm{pH}$, salinity, reducing sugar, alcohol and yeast cell count. Eighty-seven samples of Doenjang, 68 samples of Kanjang and 57 samples of Kochujang were collected and divided into conventional and improved products depending on manufacturing method. As a result, the titratable acidities of conventional Doenjang, Kanjang and Kochujang were 1.72, 1.23 and $1.25 \%$, and those of the improved products were 1.87, 1.80, and $1.00 \%$, respectively. The $\mathrm{pH}$ values of conventional Doenjang and Kochujang were lower than those of the corresponding improved products and the $\mathrm{pH}$ of conventional Kanjang was higher than improved products. The salinities of the conventional products were higher than the improved products, and an the reducing sugar and alcohol content of the conventional products were lower than the improved products. The detection rate of alcohol (above 1\%) in conventional Doenjang, Kanjang, and Kochujang were 6, 10 and 39\%, respectively while the corresponding improved products showed much higher rates of 100,76 and $100 \%$, respectively. There was no significant difference in the yeast cell count between the alcohol-containing products and the alcohol-free products. Accordingly, further study is necessary to develop a manufacturing method using non-degradable sugar and salt control to reduce the production of alcohol in Korean source.
\end{abstract}

Key words : quality characteristic, alcohol, Doenjang, Kanjang, Kochujang

\section{서 론}

장류는 쌀을 주식으로 하는 우리의 식문화로 인해 부족 한 단백질과 지방을 보충해 주는 콩을 이용한 발효식품으로 제조방식에 따라 재래식과 개량식으로 나뉠 수 있다(1). 재래식 된장은 찐 콩을 굳히면서 곰팡이나 세균에 의해 자연 발효된 메주를 소금물에 침지, 발효시켜 여액을 분리

*Corresponding author. E-mail : kjh2022@korea.kr Phone : 82-63-238-3623, Fax : 82-63-238-3843

Received 12 April 2016; Revised 23 May 2016; Accepted 26 May 2016.

Copyright (c) The Korean Society of Food Preservation. All rights reserved.
한 것이고, 반면 개량식 된장은 쌀, 밀 또는 보리 등의 전분 질 원료에 선별된 종균을 이용하여 koji를 제조하고 여기에 증자한 대두 및 소금을 혼합하여 숙성시켜 제조된다(2). 재래식 간장은 재래식 된장의 분리된 여액을 이르는 반면, 개랑식 간장은 탈지대두 또는 소맥에 균주을 배양한 koji를 이용하여 제조하거나 단백질 원료에 산 또는 효소로 가수분 해하여 제조한다(3). 재래식고추장은 불린 찹쌀을 빻아 메 주, 고춧가루, 식염 등을 혼합하여 숙성시켜 제조하며, 개량 식 고추장은 밀 또는 찹쌀 등 전분질과 고춧가루를 주원료 로 하여 koji, 소금 등을 섞어 발효시킨다(4).

장류는 사용하는 국균, 원료, 지역별 제법 등 다양한 변수 로 인해 맛 또는 제조방법을 표준화하기가 어려운 식품 중 하나이다(5). 이로 인해 장류시장에는 다양한 제조 제품 
들이 유통되고 있으며 수출 등 장거리 유통 시 효모, 세균 등 미생물의 과잉 번식으로 인해 끓어 넘치는 문제와 제품 의 맛, 향의 보조 등을 해결하는 방안으로 식품공전에서 제조 공정상 허용된 주정을 일부에서는 첨가한다(6-8). 식 품에 주정을 첨가하여 품질에 미치는 영향을 보고한 연구로 는 현미식초(9), 연근 식빵(10), 및 생면(11) 등에 적용한 사례가 있는데 주로 반죽 시에 넣거나 용해하여 넣는 방법 등을 채택하여 수행하였다. 그러나 일반적으로 장류의 경 우는 생육하는 효모에 의해 발효 중에도 자연발생적으로 알코올이 생성될 수 있어 임의로 주정을 첨가하지 않아도 다른 미생물의 증식을 크게 우려하지 않아도 된다.

최근 농림축산식품부는 세계 할랄식품 시장규모가 18 억 명에 1조6천260억 달러(2018년)에 달하고 있어 할랄시장 수출확대 방안 마련으로 할랄식품 산업 육성에 박차를 가하 고 있다. 이에 우리나라 대표 발효식품인 장류 역시 할랄지 역으로의 해외 진출을 기대하고 있지만, 발효 중 효모에 의해 알코올 생성가능성이 있어 할랄식품으로 수출 시 장애 요인이 된다. 한국 전통식품을 비롯한 다양한 상품의 수출 확대를 위해서는 선도적으로 장류 사업의 수출 활성화 방안 을 모색하여야 하는데 이에 국내 장류 업체에서 생산한 제품들의 알코올 함유량 실태 조사가 시급하며 이를 통한 할랄 식품 국제 기준에 부합된 지침 등 제시를 통해 관련 산업 진출의 토대 마련이 시급한 실정이다. 따라서 본 연구 에서는 시중에 판매되고 있는 장류 발효식품을 직접 수집하 여 알코올 함유량 및 관련 품질특성을 조사하였다.

\section{재료 및 방법}

\section{실험재료}

본 실험에 사용된 된장, 간장 및 고추장 시료는 전국의 로컬푸드점과 온라인 판매처를 통해 된장 87점, 간장 67점, 그리고 고추장 58점을 수집하여 실험 전까지 냉장보관 상 태로 유지해 두었다가 실험에 사용하였다. 이들 장류 시료 는 재래식과 개량식으로 구분하여 된장은 재래식 77점, 개 량식 10 점, 간장은 재래식 50점, 개량식 17점, 고추장은 재래식 48점, 개량식 10점이 수집되었다.

\section{시료액 제조}

된장, 간장 및 고추장의 시료액은 된장, 고추장은 $5 \mathrm{~g}$, 간장은 $2 \mathrm{~g}$ 을 증류수로 희석하여 자석교반기(MSH-20D, DAIHAN Scientific Co., Ltd., Seoul, Korea)를 이용하여 200 $\mathrm{rpm}$ 에서 1시간 동안 교반한 후 여과지(Whatman No 2, London, England)로 여과한 여과액을 시료액으로 사용하였다.

\section{$\mathrm{pH}$, 적정산도 및 염도 측정}

된장, 간장 및 고추장의 $\mathrm{pH}$ 는 시료액에 $\mathrm{pH}$ meter(Orion star a211, Thermo Scientific, Waltham, MA, USA)를 이용하 여 측정하였고 적정산도는 시료액 $10 \mathrm{~mL}$ 에 $0.5 \%$ 페놀프탈 레인을 지시약으로 $0.1 \mathrm{~N} \mathrm{NaOH}$ 로 적색이 될 때까지 적정하 여 그 함량을 계산하였다. 염도는 Mohr법(12)에 따라 시료 액 $10 \mathrm{~mL}$ 에 지시약인 $5 \% \mathrm{~K}_{2} \mathrm{CrO}_{4}$ 를 첨가하고 $0.1 \mathrm{~N} \mathrm{AgNO}_{3}$ 용액으로 미적갈색이 될 때까지 적정하여 염소량을 측정 한 후 $\mathrm{NaCl}$ 량으로 환산하였다.

\section{환원당 측정}

된장, 간장 및 고추장의 환원당은 dinitrosalicylic $\operatorname{acid(DNS,~13)~ㅂㅏㅇㅂㅓㅂㅇㅔ~ㄸㅏㄹㅏ~ㅅㅣㄹㅛ~ㅊㅜㅊㅜㄹㅇㅐㄱ~} 1 \mathrm{~mL}$ 에 DNS용액 $3 \mathrm{~mL}$ 을 혼합한 후 끓는 물에 5 분간 중탕하여 실온으로 냉각 시켰다. Microplate reader(Biotek Synergy Mx, Biotek Instruments, Winooski, VT, USA)를 사용하여 $550 \mathrm{~nm}$ 의 파 장으로 흡광도를 측정하여 표준물질로 glucose를 사용하여 검량선을 그려 상대적인 함량을 계산하였다.

\section{알코올 분석}

된장, 간장 및 고추장의 알코올 측정은 시료 $1 \mathrm{~g}$ 을 헤드스 페이스 바이알에 넣고 증류수 $1 \mathrm{~mL}$ 와 내부표준용액 100 $\mu \mathrm{L}$ 를 넣어 밀봉한 다음 5 분간 교반하여 시험용액으로 사용 하였다. 표준용액은 에탄올을 $0.1 \%, 0.5 \%, 2 \%, 4 \%$ 로 희석 하여 사용하였고, 내부표준용액은 미리 $4^{\circ} \mathrm{C}$ 에 보관한 부탄 올을 증류수에 녹여 $2.5 \% 100 \mu \mathrm{L}$ 를 사용하였다.

Gas chromatography는 HP 6890 GC(Hewlett Packard, Palo Alto, CA, USA)를 사용하였고 column은 DB-6249(60 $\mathrm{m} \times 250 \mu \mathrm{m}, 1.40 \mu \mathrm{m}$, Agilent Technologies, Palo Alto, CA, USA)을 사용하였으며, 분석 조건은 오븐온도를 $50^{\circ} \mathrm{C}$ 에서 2 분간 유지한 다음 분당 $10^{\circ} \mathrm{C}$ 씩 $140^{\circ} \mathrm{C}$ 까지 승온시킨 후 1 분간 유지하고 다시 분당 $10^{\circ} \mathrm{C}$ 씩 $250^{\circ} \mathrm{C}$ 까지 승온시켜 4 분 간 머물렀다. Injector의 온도는 $200^{\circ} \mathrm{C}$, detector(flame ionization detector)온도는 $260^{\circ} \mathrm{C}$ 로 하였고, carrier gas는 $\mathrm{N}_{2}$ 를 사용하여 유속을 $1.0 \mathrm{~mL} / \mathrm{min}$ 으로 하였다.

\section{효모수 측정}

된장, 간장 및 고추장의 효모수 측정은 시료 $1 \mathrm{~g}$ 을 멸균생 리식염수로 단계 희석한 후 건조필름배지 $\left(P e t r i f i l m^{\mathrm{TM}}\right.$ plate, $3 \mathrm{M}$ Company, St. Paul, MN, USA)에 접종하여 $25^{\circ} \mathrm{C}$ 에서 96시간 배양시켜 나타난 핑크색 또는 청초록색 colony를 계수하여 $\log \mathrm{CFU} / \mathrm{g}$ 으로 표시하였다.

\section{통계적 처리 분석}

모든 실험은 3회 반복 측정하였고, 결과는 평균값 \pm 표준 편차로 나타내었다. 각 실험구 간의 유의성 $(\mathrm{p}<0.05)$ 검증을 위해 통계적 분석은 SAS(Statistical Analysis System program, SAS Institute., Cary, NC, USA) 프로그램을 이용하 여 분산분석(analysis of variance)한 후 두 처리간에는 T-검 
정을 수행하여 $\mathrm{p}<0.05$ 수준에서 유의성을 검정하였다.

\section{결과 및 고찰}

산도 및 $\mathrm{pH}$

된장, 간장, 고추장의 산도 및 $\mathrm{pH}$ 측정 결과는 Table 1 과 같다. 산도는 발효과정 중 생성되는 유기산의 증가로 발효 기간에 따라 증가하게 되는데 재래식 된장이 $1.72 \pm 0.44 \%$, 개량식 된장이 $1.87 \pm 0.57 \%$ 로 유의적 차이를 보이지 않았 고, 재래식 간장이 $1.23 \pm 0.63 \%$, 개량식 간장이 $1.80 \pm 0.37 \%$ 로 유의적 차이를 보였으며 $(\mathrm{p}<0.05)$, 재래식 고추장이 $1.25 \pm 0.36 \%$, 개량식 고추장이 $1.00 \pm 0.27 \%$ 로 유의적 차이 를 보였다( $\mathrm{p}<0.05)$.

$\mathrm{pH}$ 변화에 따라 미생물군의 변화와 그 미생물이 분비하 는 효소 생성량에 영향을 미쳐 장류의 품질에 매우 중요한 영향을 미치게 되는데 재래식 된장이 $5.34 \pm 0.43$, 개량식 된장이 $5.48 \pm 0.20$ 로 유의적 차이를 보이지 않았고, 재래식 간장이 $5.63 \pm 0.47$, 개량식 간장이 $5.11 \pm 0.18$ 로 유의적 차이 를 보였으며 $(\mathrm{p}<0.0001)$, 재래식 고추장이 $4.82 \pm 0.26$, 개량식 고추장이 $4.98 \pm 0.12$ 로 유의적 차이를 보이지 않았다.

Lee 등(14)은 개량식 된장의 경우 발효기간이 길어질수 록 $\mathrm{pH}$ 는 감소하고, 적정산도는 증가하는 경향을 보인다고 보고하였으나 본 연구결과에서는 실험에 사용된 시료의 발효기간이 모두 달라 편차가 큰 것으로 사료된다. Cho 등(15)은 재래식 고추장이 개량식 고추장에 비해 $\mathrm{pH}$ 가 낮고
적정산도가 높다고 보고한 바 있지만 본 시료에서는 그 차이가 크지 않아, 개량식 고추장의 경우 산도 조절제나 산미료가 첨가되어 큰 차이를 보이지 않은 것으로 사료된 다. 재래식 장과 개량식 장은 숙성중의 미생물 대사 작용으 로 인해 생성되는 lactic acid 및 acetic acid 등의 유기산의 축적으로 인해 산도가 높은 것으로 보고되고 있으며(16), 이에 따라 $\mathrm{pH}$ 값도 낮아진 것으로 사료된다.

염도

된장, 간장, 및 고추장의 염도 측정 결과는 Table 1 과 같다. 염도는 미생물의 번식 및 발효 속도에 영향을 미치는 항목으로 재래식 된장이 $12.88 \pm 2.48 \%$, 개량식 된장이 $10.83 \pm 1.17 \%$ 로 유의적 차이를 보였고 $(\mathrm{p}<0.05)$, 재래식 간 장 역시 $24.61 \pm 4.54 \%$ 로 개량식 간장 $14.64 \pm 1.51 \%$ 에 비해 통계적 유의적인 차이 $(\mathrm{p}<0.0001)$ 로 높은 염도를 나타내었 으나, 고추장의 경우는 재래식이 $6.86 \pm 1.94 \%$, 개량식이 $6.20 \pm 0.56 \%$ 로 통계적 유의성 없이 큰 차이를 보이지 않았다.

$\mathrm{Kim}$ 등(17)의 포장된 전통된장과 고추장의 염도는 각각 $12.35 \%$ 와 $6.73 \%$ 로 본 연구와 유사한 결과를 나타냈으며 $\mathrm{Kim}$ 등(18)의 재래식 간장과 양조간장의 염도가 26.79 와 $16.01 \%$ 로 본 연구보다 높은 결과를 보였는데 이는 1996년 논문으로 현재는 저염식을 권장하면서 장의 염도도 감소하 는 경향이 있기 때문으로 사료된다. Jeong 등(19)의 순창전 통고추장 민속마을에서 판매하는 고추장의 경우 6.43 $10.84 \%$ 의 염도를 보이며 염 함량의 차이는 물엿이나, 설탕 등의 숙성된 고추장의 늘리기 과정에서 첨가량이 다르기

Table 1. Quality characteristics of Doenjang, Kanjang and Kochujang between conventional and improved products

\begin{tabular}{cccccc}
\hline Groups & \multicolumn{5}{c}{ Quality characteristics (\%) } \\
\cline { 2 - 6 } & Titrable acidity & $\mathrm{pH}$ & Salinity & Reducing sugar & Alcohol \\
\hline Doenjang & & & & & \\
Total & $1.74 \pm 0.45^{1)}$ & $5.35 \pm 0.41$ & $12.64 \pm 2.45$ & $2.07 \pm 2.56$ & $0.45 \pm 0.91$ \\
Conventional & $1.72 \pm 0.44$ & $5.34 \pm 0.43$ & $12.88 \pm 2.48$ & $1.44 \pm 1.54$ & $0.18 \pm 0.51$ \\
Improved & $1.87 \pm 0.57$ & $5.48 \pm 0.20$ & $10.83 \pm 1.17$ & $6.92 \pm 3.60$ & $2.53 \pm 0.45$ \\
p-value ${ }^{2)}$ & 0.3182 & 0.0915 & 0.0002 & 0.001 & $<0.0001$ \\
Kanjang & & & & $1.90 \pm 2.60$ & $1.11 \pm 1.80$ \\
Total & $1.39 \pm 0.62$ & $5.50 \pm 0.47$ & $22.08 \pm 5.91$ & $0.65 \pm 0.42$ & $0.36 \pm 1.08$ \\
Conventional & $1.23 \pm 0.63$ & $5.63 \pm 0.47$ & $24.61 \pm 4.54$ & $5.56 \pm 2.86$ & $3.11 \pm 1.86$ \\
Improved & $1.80 \pm 0.37$ & $5.11 \pm 0.18$ & $14.64 \pm 1.51$ & $<0.0001$ & $<0.0001$ \\
p-value & $<0.0001$ & $<0.0001$ & 0.0002 & & $19.42 \pm 5.81$ \\
Kochujang & & & & $18.29 \pm 5.41$ & $1.39 \pm 1.82$ \\
Total & $1.20 \pm 0.36$ & $4.84 \pm 0.25$ & $6.75 \pm 1.79$ & $1.24 \pm 1.97$ \\
Conventional & $1.25 \pm 0.36$ & $4.82 \pm 0.26$ & $6.86 \pm 1.94$ & $24.85 \pm 4.63$ & $2.12 \pm 0.38$ \\
Improved & $1.00 \pm 0.27$ & $4.98 \pm 0.12$ & $6.20 \pm 0.56$ & 0.0007 & 0.0049 \\
p-value & 0.0416 & 0.0075 & 0.1017 & &
\end{tabular}

\footnotetext{
${ }^{1)}$ Mean \pm SD.

2) independent two-sample t-test.
} 
때문이라고 보고하였다.

결론적으로 본 연구에서 사용한 시판 장류의 평균 염도 는 재래식이 개량식에 비해 높음을 알 수 있었다. 재래식 장의 경우 다양한 미생물이 발효에 관여하고, 살균처리 없 이 장기간 숙성되기 때문에 저장성을 높이기 위해 종국을 이용해 짧은 시간 발효하는 개량식 장보다 높은 염도를 보이는 것으로 보고되고 있다(17).

\section{환원당}

된장, 간장 및 고추장의 환원당 측정 결과는 Table 1 과 같다. 환원당은 된장 숙성 초기에 미생물에 의해 분비된 효소에 의해 높았다가 숙성이 진행됨에 따라 된장 내 미생 물의 영양원, 유기산 발효의 기질로 이용되면서 수치가 감 소하게 된다. 본 실험에서는 재래식 된장이 $1.44 \pm 1.54 \%$, 개량식 된장이 $6.92 \pm 3.60 \%$ 이었고 재래식 간장이 $0.65 \pm$ $0.42 \%$, 개량식 간장이 $5.56 \pm 2.86 \%$ 로 개량식이 통계적으로 높은 값을 보였으며( $<0.0001)$, 재래식 고추장 역시 $18.29 \pm$ $5.41 \%$ 로 개량식 고추장의 환원당 $24.85 \pm 4.63 \%$ 값에 비해 유의적으로 낮은 값을 나타내었다( $\mathrm{p}<0.05)$.

Yoo 등(20)의 전통된장에서 분리된 균을 이용한 된장의 환원당 함량은 5.07 11.34\%로 시료간의 차이는 균종에 따 라 amylase 활성이 다르기 때문이라고 보고하였다. Joo 등 (21)의 전통간장의 환원당 함량은 $0.72 ~ 1.01 \%$ 의 범위로 본 시료와 유사한 결과를 나타내었다. $\mathrm{Kim}$ 등(22)의 순창 고추 장민속마을에서 생산한 전통 된장의 환원당 함량은 평균 $2.38 \%$, 전통 고추장은 $19.25 \%$ 로 본 시료와 유사한 결과를 나타내었다. Park(29)은 고추장의 전분질 원료에 따라 환원 당 생성량의 차이를 발견하였고 알코올 생성속도와 부합된 다고 보고한바 있다.

따라서 본 연구결과에서처럼 시판 장류의 환원당 함량이 개량식이 재래식에 비해 통계적으로 높은 값을 보인 것은 Chae 등(24)의 보고와 같이 재래식 장의 경우 콩이 주재료 이지만 개량식 장의 경우 소맥분으로 숙성 초기에 amylase 와 같은 효소에 의해 전분질이 분해되어 환원당이 높게 검출된 것으로 생각된다.

\section{알코올 함량}

된장, 간장 및 고추장의 알코올 측정 결과는 Table 1 에 제시하였다. 알코올은 미생물 발효작용에 의해 당이 알코 올로 전환되어 생성될 수 있는데 본 실험에서는 주정이 첨가된 시료와 구분하여 그 함유량을 조사하였다. 그 결과 재래식 된장이 $0.18 \pm 0.51 \%$, 개량식 된장이 $2.53 \pm 0.45 \%$ 로 유의적 차이로 개량식이 높았고 $(\mathrm{p}<0.0001)$, 간장 역시 재래 식이 $0.36 \pm 1.08 \%$, 개량식이 $3.11 \pm 1.86 \%$ 로 통계학적으로 유의성 있게 개량식이 높은 값을 보였으나 $(\mathrm{p}<0.0001)$, 고추 장 역시 재래식 $1.24 \pm 1.97 \%$ 에 비해 개량식이 $2.12 \pm 0.38 \%$ 로 높았지만, 통계적 유의성은 없었다.

Table 2는 본 연구에서 사용된 장류들을 검출된 알코올 농도에 따라 구분하여 분포도를 살펴 본 것이다. 장류 중 $1 \%$ 이상 알코올이 함유된 시료들 중 재래식과 개량식으로 구분하여 보면 재래식의 경우 된장, 간장, 그리고 고추장이 $6.5,10,39.6 \%$ 이고, 개량식의 경우 된장, 간장, 고추장이 각각 $100,76.5$, 그리고 $100 \%$ 로 개량식이 높은 검출율을 나타내었다. 또한 된장과 간장의 경우 각각 $39 \%$ 와 $40 \%$ 로 재래식에서만 알코올이 불검출되어 재래식 장과 개량식 장간에 차이가 컸는데, 이는 주정의 첨가 유무에 따른 것으 로 판단된다. 그러나 고추장의 경우 재래식 고추장에서 $0.5 \sim 1.0 \%$ 농도에서 검출된 시료가 $19 \%$ 이고, $0.5 \%$ 미만의 알코올을 함유한 시료는 약 $42 \%$ 로 나타나 재래식 고추장에 도 주정이 들어가는 시료가 있음을 알 수 있었다.

이와 같이 알코올 함량이 차이가 나는 원인으로 Choo와 Shin(25)은 전분질원, 메주의 활성도, 숙성조건 등이 있다고 추측하였으며 일부 제조업체에서 미생물제어를 위해 주정 을 첨가하여 판매하는 것으로 보고하고 있다(26).

\section{효모수}

효모는 특히 된장 발효 중 자연적으로 발생하여 에탄올 등 알코올을 생성하고, 그 생성된 알코올에 의해 생육이 억제되기도 한다. 본 실험에서는 된장, 간장 및 고추장 중 원재료에 주정 사용 여부가 미표시되고, 알코올 함량이 높 은 시료를 선정하여 효모수를 측정하여 그 결과를 Table

Table 2. Distribution of alcohol content in Doenjang, Kanjang and Kochujang

\begin{tabular}{|c|c|c|c|c|c|c|}
\hline \multirow{2}{*}{\multicolumn{2}{|c|}{ Samples }} & \multicolumn{4}{|c|}{ Alcohol content (detection rate, \%) } & \multirow[b]{2}{*}{ Total } \\
\hline & & $>1 \%$ & $0.5 \sim 1.0 \%$ & $0 \sim 0.5 \%$ & $0 \%<$ & \\
\hline \multirow{2}{*}{ Deonjang } & Conventional & $5(6.5)$ & $3(3.9)$ & 39 (50.6) & $30(39.0)$ & 77 \\
\hline & Improved & $10(100.0)$ & $\mathrm{ND}^{1)}(0.0)$ & $\mathrm{ND}(0.0)$ & $\mathrm{ND}(0.0)$ & 10 \\
\hline \multirow{2}{*}{ Kanjang } & Conventional & $5(10.0)$ & $\mathrm{ND}(0.0)$ & $25(50.0)$ & $20(40.0)$ & 50 \\
\hline & Improved & $13(76.5)$ & $\mathrm{ND}(0.0)$ & $4(23.5)$ & $\mathrm{ND}(0.0)$ & 17 \\
\hline \multirow{2}{*}{ Kochujang } & Conventional & $19(39.6)$ & $9(18.8)$ & $20(41.7)$ & $\mathrm{ND}(0.0)$ & 48 \\
\hline & Improved & $10(100.0)$ & $\mathrm{ND}(0.0)$ & ND $(0.0)$ & $\mathrm{ND}(0.0)$ & 10 \\
\hline
\end{tabular}

\footnotetext{
${ }^{1)}$ Not Detected.
} 
3에 제시하였다. 된장의 경우 알코올 함량이 가장 높게 나왔 던 시료에서는 효모가 불검출 되었지만, 다른 시료에서는 $1.74 \sim 6.56 \log \mathrm{CFU} / \mathrm{mL}$ 로 나타났다. 간장의 경우 알코올 함량이 $3.38 \%$ 나왔던 개량식 장에서 $3.3 \log \mathrm{CFU} / \mathrm{mL}$ 로 나왔고, $1.19 \%$ 의 알코올을 함유한 재래식 장에서 $2 \log$ $\mathrm{CFU} / \mathrm{mL}$ 로 나타났다. 고추장의 경우 알코올 함량이 $7.06 \%$ 였던 시료에서는 불검출되었고, 2.41 과 $0.01 \%$ 알코올이 검 출된 시료에서는 각각 3.28 과 $3.48 \log \mathrm{CFU} / \mathrm{mL}$ 로 효모가 검출되었다.

Lee와 $\mathrm{Oh}(27)$ 는 시간이 흐름에 따라 효모수가 증가하면 서 알코올이 생성된 것으로 판단하였으나 본 연구 결과에서 재래식 장과 개량식 장간의 차이를 발견할 수 없어 효모의 존재만으로 장류 발효 중 알코올이 생성되었다고 판단할 수는 없고 향후 실험실 수준에서 장류를 제조하여 효모수 증가에 따른 알코올 생성량 변화를 모니터링하는 연구를 통해 상관성을 구명할 수 있을 것으로 사료된다.
효모수를 측정한 결과 검출 유무가 알코올 함량과 연관성이 없어 효모의 존재만으로 알코올을 생성하였다고 판단할 수 없었다. 지금까지 결과를 종합해보면 개량식 된장에 비 해 낮은 환원당을 나타낸 재래식 된장의 경우 알코올 발효 의 기질로 사용될 당이 부족하기 때문에 낮은 알코올 값을 보인 것으로 사료되고, 개량식 간장의 경우 재래식 간장보 다 낮은 염도를 나타내기 때문에 균의 활동이 비교적 활발 하여 산도와 알코올 함량이 높은 것으로 사료된다. 할랄식 품 시장 진출을 위한 알코올을 함유하지 않은 장을 만들기 위해서는 난분해성 당을 사용하고 염도를 높여 균 활동을 억제하는 추가적인 연구가 필요할 것으로 보인다.

\section{감사의 글}

본 연구는 농촌진흥청 어젠다사업(과제번호 : PJ01000501) 의 지원에 의해 이루어진 결과로 이에 감사드립니다.

Table 3. Viable cell counting of yeast in Doenjang, Kanjang and Kochujang containing alcohol

\begin{tabular}{|c|c|c|c|c|c|c|}
\hline & \multicolumn{2}{|c|}{ Doenjang } & \multicolumn{2}{|c|}{ Kanjang } & \multicolumn{2}{|c|}{ Kochujang } \\
\hline & Alcohol content $(\%)$ & $\log \mathrm{CFU} / \mathrm{mL}$ & Alcohol content $(\%)$ & $\log \mathrm{CFU} / \mathrm{mL}$ & Alcohol content $(\%)$ & $\log \mathrm{CFU} / \mathrm{mL}$ \\
\hline \multirow{6}{*}{ Conventional } & 1.36 & $\mathrm{ND}^{1)}$ & 4.09 & $\mathrm{ND}$ & 7.06 & $\mathrm{ND}$ \\
\hline & 0.82 & 5.68 & 3.12 & $\mathrm{ND}$ & 2.41 & 3.28 \\
\hline & 0.82 & 6.56 & 0.14 & ND & 0.01 & 3.48 \\
\hline & 0.71 & 4.41 & 1.19 & 2.00 & & \\
\hline & ND & 4.48 & $\mathrm{ND}$ & $\mathrm{ND}$ & & \\
\hline & ND & 4.02 & ND & $\mathrm{ND}$ & & \\
\hline \multirow{6}{*}{ Improved } & 1.83 & 0.00 & 0.03 & $\mathrm{ND}$ & 2.08 & $\mathrm{ND}$ \\
\hline & 2.46 & 0.00 & 4.24 & $\mathrm{ND}$ & & \\
\hline & 2.32 & 3.94 & 3.38 & 3.30 & & \\
\hline & 2.33 & 1.74 & 0.26 & $\mathrm{ND}$ & & \\
\hline & 2.51 & $\mathrm{ND}$ & 0.24 & $\mathrm{ND}$ & & \\
\hline & 2.20 & ND & 0.27 & ND & & \\
\hline
\end{tabular}

${ }^{11}$ Not Detected.

\section{요 약}

본 연구는 시판 장류의 알코올 함유량 및 관련 품질특성 을 파악하고자 산도, $\mathrm{pH}$, 염도, 환원당, 알코올 함량 및 효모 수를 조사하였다. 산도는 재래식 된장과 간장이 개량식보 다 낮게 나타났고, 재래식 고추장이 개량식보다 높게 나타 났으며, $\mathrm{pH}$ 는 재래식 된장과 고추장이 개량식보다 낮게 나타났고, 재래식 간장이 개량식보다 높게 나타났다. 염도 는 재래식 장이 개량식 장보다 모두 높게 나타났고, 환원당 과 알코올은 재래식 장이 개량식 장보다 모두 낮게 나타났 다. 또한 주정 무첨가된 시료 중 알코올이 검출된 장류 중에

\section{References}

1. Kim EB, Kim EJ, Lee HN, Lee MK, Oh JS, Kim SO, Lee SY (2008) The quality characteristics of soy cutlets using textured soy protein treated with different enzymes. Korean J Food Culture, 23, 507-513

2. Lee SW, Park YW, Chang PS, Lee JH (2010) Isoflavone distribution and $\beta$-glucosidase activity in home-made and factory-produced Doenjang. Korean J Food Sci Technol, 42, 125-129

3. Chae HJ, In MJ, Kim MH (1997) Production and 
characteristics of enzymatically hydrolyzed soy sauce by the treatment using proteases. J Korean Soc Food Sci Nutr, 26, 784-787

4. Jin SK, Kim IS, Hah KH, Park KH, Kim IJ, Lee JR (2006) Changes of $\mathrm{pH}$, acidity, pretense activity and microorganism on sauces using a Korean traditional seasonings during cold storage. Korean J Food Sci Ani Resour, 26, 159-165

5. Kim DH, Kang SW, Kim SH (1999) Production of korean traditional soy sauce from Rhizopus stolonifer inoculated grain type meju. Korean J Food Sci Technol, 31, 757-763

6. Kim GT, Hwang YI, Lim SI, Lee DS (2000) Carbon dioxide production and quality changes in Korean fermented soybean paste and hot pepper-soybean paste. J Korean Soc Food Sci Nutr, 29, 807-813

7. Kim YS, Jung HJ, Park YS, Yu TS (2003) Characteristics of flavor and functionality of Bacillus subtilis K-20 chunggukjang. Korean J Food Sci Technol, 35, 475-478

8. KFDA (2011) Korea Food and drug administraion, Korea, 166-168

9. Kim GR, Yoon SR, Lee JH, Yeo SH, Kim TY, Jeong YJ, Yoon KY, Kwon JH (2009) Quality comparison of commercial brown rice vinegar fermented with and without ethanol. Korean J Food Preserv, 16, 893-899

10. Seo EO, Choi EO, Yun YS, Chung BW (2008) Effects of ethanol on the characteristics of white bread containing lotus root powder. J East Asian Soc Dietary Life, 18, 64-71

11. Lee JY, Lim CW, Ha SD (2009) Extending shelf-life with addition of ethanol of wet noodles. J Fd Hyg Safety, 24, 348-351

12. Kang JE, Choi HS, Choi HS, Park SY, Song J, Choi JH, Yeo SH, Jung ST (2013) The quality characteristics of commercial Doenjang certified for traditional foods. Korean J Connumity Living Sci, 24, 537-542

13. Kim YS, Kim JY, Choi HS (2011) Quality characteristics of commercial rice soybean paste. Korean J Food Preserv, $18,853-858$

14. Lee SW, Shin SY, Yu TJ (1985) Effects of the ethanol contents on the preparation of low salt Doenjang. Korean J Food Sci Technol, 17, 336-339

15. Cho HO, Park SA, Kim JG (1981) Effect of traditional and improved Kochujang koji on the quality improvement of traditional Kochujang. Korean J Food Sci Technol,
13, 319-327

16. Chang M, Kim IC, Chang HC (2010) Effect of solar salt on the quality characteristics of Doenjang. J Korean Soc Food Sci Nutr, 39, 116-124

17. Park SK, Seo KI, Choi SH, Moon JS, Lee YH (2000) Quality assessment of commercial Doenjang prepared by traditional method. J Korean Soc Food Sci Nutr, 29, 211-217

18. Kim YA, Kim HS, Chung MJ (1996) Physicochemical analysis of Korean traditional soy sauce and commercial soy sauce. Korean J Soc Food Sci, 12, 273-279

19. Jeong DY, Song MR, Shin DH (2001) Studies on the physicochemical characteristics of Sunchang traditional Kochujang. Korean J Food Culture, 16, 260-267

20. Yoo SK, Kang SM, Noh YS (2000) Quality properties on soy bean pastes made with microorganisms isolated from traditional soy bean pastes. Korean J Food Sci Technol, 32, 1266-1270

21. Joo MS, Sohn KH, Park HK (1997) Changes in taste characteristics of traditional korean soy sauce with ripening period (I)-analysis of general compounds and sugars. Korean J Dietary Culture, 12, 183-188

22. Kim JW, Kim YS, Jeong PH, Kim HE, Shin DH (2006) Physicochemical characteristics of traditional fermented soybean products manufactured in folk villages of Sunchang region. J Fd Hyg Safety, 21, 223-230

23. Park SW, Park YJ (1979) Studies on the chemical compositions and quality of red pepper paste brewed with different raw materials. Korean J Food Sci Technol, 6, 205-212

24. Chae IS, Kim HS, Ko YS, Kang MH, Hong SP, Shin DB (2008) Effect of citrus concentrate on the physicochemical properties of Kochujang. Korean J Food Sci Technol, 40, 626-632

25. Choo JJ, Shin HJ (2000) Sensory evaluation and changes in physiochemical properties, and microflora and enzyme activities of pumpkin-added Kochujang. Korean J Food Sci Technol, 32, 851-859

26. Mok CK (2005) Effect of ethanol addition on growth of microorganisms in soybean paste (Doenjang). Food Engineering Progress, 9, 161-164

27. Lee NS, Oh NS (1996) Characteristics of yeast flora and gas generation during fermentation of Doenjang. Agric Chem Biotechnol, 39, 255-259 